\title{
Simulating future work activity is not only a way of improving workstation design
}

François Daniellou

\section{(2) OpenEdition \\ 12 Journals}

\section{Electronic version}

URL: http://journals.openedition.org/activites/1704

DOI: 10.4000 /activites. 1704

ISSN: $1765-2723$

\section{Publisher}

ARPACT - Association Recherches et Pratiques sur les ACTivités

\section{Electronic reference}

François Daniellou, «Simulating future work activity is not only a way of improving workstation design », Activités [Online], 4-2 | octobre 2007, Online since 15 October 2007, connection on 02 May 2019. URL : http://journals.openedition.org/activites/1704; DOI : 10.4000/activites.1704

\section{(ब) $(\oplus \Theta$}

Activités est mis à disposition selon les termes de la licence Creative Commons Attribution - Pas d'Utilisation Commerciale - Pas de Modification 4.0 International. 


\title{
Simulating future work activity is not only a way of improving workstation design
}

\author{
François Daniellou \\ Laboratoire d'Ergonomie des Systèmes Complexes, \\ Université Victor Segalen Bordeaux 2 Case 55, 146 rue Léo-Saignat, F33076 BORDEAUX Cedex \\ francois.daniellou@idc.u-bordeaux2.fr
}

\begin{abstract}
Ergonomic simulations may be classified according to the role that they assign to the future users, which may either be modelled in technical tools, subjects of controlled experiments, or participants in a participatory process. In the latter case, simulations may produce more than technical improvements. They may result in new developments of individual and collective activity.
\end{abstract}

KEYWORDS

Simulation, participatory ergonomics, theory of practice.

\section{1.- Simulating for or with the users?}

Simulations of workstations may be used in many industrial or tertiary contexts with various aims. Three major indications are i) the assessment, at the stage of design, of different features of the users' future activity, in order to diagnose possible problems; ii) the analysis of cognitive processes in situations that are difficult to provoke and/or to observe in reality; and iii) the training of workers (Pastré, 2005). The present paper only deals with simulations that are used at the design stage to anticipate some of the features of a future workstation or work system, notably from an ergonomic standpoint.

The terms "ergonomic simulation" have now become commonplace, and their search on Internet yields hundreds of commercial proposals. But this generalization appears to overshadow fundamental differences between the many uses of ergonomic simulations in design processes.

One way of classifying different approaches to the simulation of work systems is to consider the status of the users in the course of the simulation: -a) in many cases there are no physically present users, those are modelled (by means of a manikin, a computer programme, etc.) within design tools used by the designers, with or without the help of an ergonomist; -b) sometimes, users or "user-similar" individuals are requested to take part in a controlled experiment, and their behaviour is analyzed by an ergonomic expert, who will or will not interview the experimental subjects on their feelings about the simulated system and its usability; -c) finally, the users may be participants in a participatory ergonomic process, where simulation is one of the components of a more global involvement of different actors in the design process (Haslegrave, Wilson, \& Corlett, 1990; Wilson, 1991).

This categorization is distinct from one that could be based on the technical means that are used for the simulation: for instance, virtual reality a) may be used by the design team to make simulations without involving any user, or b) it may be supporting an experimental approach, or c) it may be used in the frame of a design work group involving different users who will question the design choices. 


\section{1.- Interests and limitations of expert-led technical simulations}

Simulations carried out by designers or ergonomists by means of technical tools that do no involve the users' presence presuppose a triple modelling: a model of the Human, a model of the work system, and a model of the work to be performed.

The model of the Human is usually a more or less sophisticated anthropometric model. In some cases, biomechanical data are embedded, such as the taking in account of angles or efforts. Perceptive dimensions may also be included (e.g. visibility).

The models of the work system and of the work to be performed may refer to normal situations, as they are considered by the designers. Or, they may include a reference to industrial variability, incidents, and adjustments that the workers will have to make.

For instance, simulation of the reach areas on an assembly line may be based only on the normal cycle time. Or it may take in account the fact that all cycles are different and that, due to incidents, the worker may be late or in advance. This will lead to completely different conclusions as to the required space to be left for the workstation (probably in a 2:1 ratio). The simulation of the monitoring of a machine may yield totally wrong results if the monitoring strategy of the workers has not been correctly anticipated, through an analysis of what they consider the critical points of the process.

Therefore, highly sophisticated models of anthropometric data are in no way a guarantee that the workstation will be appropriate, even from a merely anthropometric point of view. The critical point is the questioning of the models of the work system and of the activity that will take place, given that the designers are just not in a position to tell how people will actually work.

If the use of basic simulations by the designers alone may prevent major design mistakes

(e.g. the taking in account of anthropometric diversity), too sophisticated technical tools may support the illusion of "ergonomically designed" workplaces, where the only work that has been considered is the one that is fancied by the designers. A previous analysis of the work determinants and of possible strategies to cope with them is essential.

\section{2.- Interests and limitations of controlled experimental simulations}

The second category of simulations refers to the construction of an experimental device, that will simulate the work environment and the dynamics of the process, including the results of the users' actions. A set of tasks to be performed defines the scenario of the experiment. The actions of the subject(s) and the dynamics of the simulated process are recorded. The results are interpreted by the analyst(s) (e.g. the ergonomist), and will be used to influence the design decisions.

There is an extensive literature about the validity and fidelity of such simulators (Nyssen, \& De Keyser, 1998). Their main interest is the possibility to analyze some features of the subjects' activity in detail, including in situations that will hopefully never occur in reality.

The point here is again to discuss the status of the "subjects" in such an experiment when it is part of a design process. Leaving aside the cases where the subjects are students, individuals contracted for the sake of the experiment, or clerks whose jobs have nothing to do with the one that is simulated, we'll only consider the situation where the subjects have similar professional characteristics to the future users (Reuzeau, 2001).

In some cases, the subjects are placed in a strictly experimental context. Their behaviour is analyzed and interpreted, but they are not supposed to influence in any way the experimental settings. The model of the work to be realized is supposed to be unquestionable.

In other situations, the subjects are welcome to interfere with the preset settings of the experiment, e.g. by suggesting new simulation scenarios. This contribution may also be done by the "instructor" who in some cases steers the simulator and will introduce non expected events he/she feels plausi- 
ble. The subjects or the instructor are then regarded as design partners. This configuration possesses some, but not all of the properties of participatory simulations that will be discussed below.

\section{2.- Simulations as components of a participatory approach}

In participatory ergonomics approaches, groups of workers are invited to take part in simulations about the future work system. Participation has been defined by Wilson (1991) as the involvement of people in planning and controlling a significant amount of their own work activities, with sufficient knowledge and power to influence both processes and outcomes in order to achieve desirable goals.

Various schemes of worker participation to design processes have been documented. Some lay the emphasis on the creativity of worker groups to invent satisfactory design solutions at the onset of the design process (e.g. decision design groups, Wilson, 1991). Some are structured over time to match the overall structure of the design process, and to foster an ongoing confrontation between the designers' proposals and the corresponding possible future work activity (Daniellou, Garrigou, Kerguelen, \& Laville, 1990; Garrigou, Danellou, Carballeda, \& Ruaud, 1995).

\subsection{Basic ingredients for a participatory simulation}

In this case, groups of workers are set. They will meet at repeated occasions during the design process. The current state of the design studies is presented, and a simulation of its consequences for future work activity is carried out. A prognosis is made, possibly leading to modifications in the design decisions.

The basic components of such an approach are:

- the social construction of the overall participatory process;

- the choice of the participants;

- the choice of the simulation media and the type of simulation;

- the choice of simulation scenarios.

The social construction of the participatory process should ensure the articulation of the decision processes at the levels of the political and technical project leaders, of technical studies, of personnel representatives, and of the simulation work groups. The role of each group should be explicit.

The choice of the participants is based on the types of professional knowledge that are required to perform the simulation. Not only production workers, but also maintenance, supply, control workers etc. may be associated. One key issue is the presence of the middle managers and executives, who in some cases may be members of the same groups while in others they will constitute a separate group.

The current design state of the future work environment is represented by various media, such as drawings, models, mock-ups, computerized models, prototypes, etc. Those have different properties (Maline, 1994).

According to the properties of the available media, two main types of simulations are possible (Daniellou, 2005). An experimental simulation may be carried out on a prototype, while in the case of drawings or reduced-scale models, a narrative simulation is relevant: the participants build up a detailed oral account of feasible ways of carrying the future tasks. Its likelihood and possible problems are collectively discussed.

The choice of the scenarios is based on the previous analysis of reference existing situations, that entail some of the sources of variability that will be encountered in the future system (Daniellou, \& Garrigou, 1992). These scenarios are previously prepared by the ergonomist, but they are discussed 
and completed by the group.

The simulation makes possible an assessment of health hazards, difficulties to meet the quality requirement, probable errors, etc. Minor problems detected by the simulation may be corrected in real time when the project leader is present, while more serious problems will require further studies or negotiations, and another simulation session.

\section{2.- Future activity may not be forecast}

The aim of the simulations is to approach the future activity of the users, and to note the problems which may arise, in terms of health or efficiency. But a theoretical point has to be noted: the real users' activity may no be forecast. Nobody can say in advance what Mrs X will do in the main hall of a future hospital. But design decisions open up or close entire avenues to the future activities: some forms of activity are made possible, while others are prevented.

The aim of the simulation is not to prescribe the right way of performing the tasks. It is to assess what are the possible forms of future activity and whether they are acceptable, according to the ergonomic criteria. It is possible that real users might invent working strategies that have not been anticipated in the course of the simulation. But the simulation should check that, under all foreseeable circumstances, there is always at least one acceptable way of performing the tasks.

\section{3.- Results and effects of participatory simulations}

The best known result of participatory simulations is of course the possibility to detect properties of the designed work system that would lead to hazards or malfunctionings, and to enable the correction of these problems at an early stage of the design process rather than after start-up.

But participatory simulations may produce other effects and benefits than those relating to the design of the technical system. Major outcomes are i) the formative benefits and ii) the effects of the confrontation of different "worlds".

\section{Formative and developmental benefits}

We follow the perspective presented by Rabardel and Beguin (2005), about the difference between an artefact and an instrument. The instrument is a mixed entity, made up of the technical artefact on the one hand, and "utilization schemes" that are developed by the user, on the other hand. Those schemes are the invariants that will organize his/her activity. For the artefact to become an instrument for the users, an "instrumental genesis" is required: it combines the development of utilization schemes by the users and some modifications of the artefact that might be introduced by the users to "tailor" it.

Repeated simulations sessions on a work system are an excellent frame to initiate this process of instrumental genesis. The future users explore the characteristics of the new system, in different situations of use, and may therefore start to develop utilization schemes. They also have an influence on the design of the artefact, and may to some extent contribute to its adaptation.

The workers who have taken part in the simulation process usually show at start-up a mastery of the new system that is much better than the one of the workers who have only undergone ordinary training programmes.

This may be interpreted in terms of "development of their activity" (Béguin, \& Clot, 2004) during the simulation sessions.

\section{The encounter of worlds}

Simulations that gather together individuals belonging to different professional worlds are also the opportunity of an "encounter" of these worlds. The different worlds that will meet may be e.g. the 
one of the designers, the one of production operators, the one of production engineers etc.

Each participant may discover that, in the company, there are different viewpoints which do not regard the workplace from the same angle, which highlight different constraints that are all combined in the workplace, and which do not value the same aspects of the work which takes place there. It is also an opportunity to realize that these differences are not a matter of personal opinion, that there are not "good" and "evil" interpretations, that all the viewpoints are necessary to keep the system running, but that they may not spontaneously compatible. This confrontation opens up the possibility of debates leading to shared interpretations of the work determinants.

These differences in viewpoints may, as a first approach, be considered as differences in representations of the workplace and its problems, or in different "socio-cognitive orientations" of the participants (Garrigou, et al., 1995). But Béguin (2005) states that they are more than that. Each professional category does not only perceive the work situation from a distinct perspective. They will also act in order to maintain the process dynamics within their "world", i.e. within the limits of what they are able to manage.

The simulations may be an opportunity to bring to the fore that there are sets of situations that are commonly mastered in one "world" or other, while other possible situations are not likely to be properly managed in any of the existing "worlds". This situation is most common in chemical plants, where neither the world of everyday control, nor the one of engineering and calculation are able to cope with extreme situations that the simulation may reveal. This discovery emphasizes that there is a common world of issues to be investigated (Béguin, 2005).

Such findings may lead to changes in the social fabric of the organization, and in the relations between various professional groups.

\section{3.- Discussion}

Simulations of the future workplace appear to be a touchstone of theoretical debates about the nature of ergonomics and its contribution to work improvement.

One position is to consider that ergonomics may be regarded as a technology that applies fundamental knowledge about human physiology and cognitive psychology to improve the design of workplaces. From this perspective, work is not an issue. Every designer, every ergonomist knows what work is, and may apply to it the expertise that stems from his/her professional education. They may serenely use technical simulation tools to assess the acceptability of a design proposal, without questioning their own representation of the work that will take place.

Another position is to consider that ergonomics is a practice (Daniellou, 1999) that endeavours to foster debates, design processes and decisions that take in account the complexity of the processes that permit production of goods or services within an organization. From this perspective, work activity is not merely the carrying out of the prescribed tasks. It entails coping with unpredicted variability, mobilizing personal and collective resources, experiencing contradictions and debates about values; it implies personal costs and social contradictions. The ergonomist has a role in the understanding of this density of the work activity and in the new avenues that may be opened to its development. As Wilson states: "In this role, we are craftspeople, using judgement, vision, experience and even trial and error to develop and test concepts and prototypes" (Wilson, 2000).

If so, ergonomics has to reinforce its interfaces not only with physiology and cognitive psychology, but also with social sciences and developmental psychology. And ergonomists need to have debates on models not only of the Human at work, but of their own activity (Daniellou, 1999). 


\section{REFERENCING}

Daniellou, F. (2007). Simulating future work activity is not only a way of improving workstation design. @ectivités, 4 (2), pp. 84-90, http://www.activites.org/v4n2/v4n2.pdf

\section{REFERENCES}

Béguin, P. (2005). Concevoir pour les genèses professionnelles. In P. Rabardel, \& P. Pastré (Eds.), Modèles du sujet pour la conception (pp. 31-52). Toulouse: Octarès Editions.

Béguin, P, \& Clot, Y. (2004). Situated action in the development of activity. @ctivités, 2004, 1 (2), 50-63, http://www.activites.org/v1n2/beguin.eng.pdf

Daniellou, F., (1999). The ergonomist is a worker? That is the (epistemological) question. In N. Marmaras (Ed.), Strengths and weaknesses, threats and opportunities of ergonomics in front of 2000. Athens: The Hellenic ergonomics society.

Daniellou, F., (2004). L'ergonomie dans la conduite de projets de conception de systèmes de travail. In P. Falzon (Ed.), Traité d'ergonomie (pp. 359-373). Paris: PUF

Daniellou, F. (2005). How far can future activity be foreseen ? Proceedings of First ISCAR Congress, Acting in changing worlds, Universidad de Sevilla and Universidad Pablo Olavide de Sevilla.

Garrigou, A., Daniellou, F., Carballeda, G., \& Ruaud, S. (1995). Activity analysis in participatory design and analysis of participatory design activity. International Journal of Industrial Ergonomics, 15 (5), 311-327.

Daniellou, F., \& Garrigou, A. (1992). Human Factors in design: sociotechnics or ergonomics. In M. Helander, \& M. Nagamachi (Eds.), Design for manufacturability (pp. 53-63). London: Taylor and Francis.

Daniellou, F., Garrigou, A., Kerguelen, A., \& Laville, A. (1990). Taking future activity in account at the design stage : participative design in the printing industry. In C.H. Haslegrave, J.R.Wilson, E.N. Corlett, \& I. Manenica (Eds.), Work design in practice, Proceedings of the Third. International Occupational Ergonomics Symposium Zadar (pp. 189-196). London: Taylor and Francis.

Haslegrave, C., Wilson, J.R., \& Corlett E.N. (1990). Work design in practice. Proceedings of the $3^{\text {rd }}$ International Occupational Ergonomics Symposium Zadar. London: Taylor and Francis.

Maline, J. (1994). Simuler le travail : une aide à la conduite de projet. Lyon: Anact (Outils et Méthodes).

Nyssen, A.S., \& De Keyser, V. (1998). Improving training in problem solving skills: analysis of anesthetist's performance in simulated problem situations. Le Travail Humain, 61 (4), 387-401.

Pastré, P. (2005). Apprendre par la simulation. Toulouse: Octarès Editions.

Rabardel, P., \& Béguin, P. (2005). Instrument mediated activity: from subject development to anthropocentric design. Theoretical Issues in Ergonomics Science, 6 (5), 429-461.

Reuzeau, F. (2001). Finding the best users to involve in design : a rational approach. Le Travail Humain, 64 (3), 223-245.

Wilson, J.R. (1991). Ergonomics and participation. In: J.R. Wilson, \& E.N. Corlett (Eds.), Evaluation of Human Work (pp. 1071-1096). London: Taylor and Francis.

Wilson, J.R., (2000). Fundamentals of ergonomics in theory and practice. Applied ergonomics, 31, 557-567.

\section{RÉSUMÉ}

On peut catégoriser les simulations ergonomiques selon la place qu'elles attribuent aux futurs utilisateurs : ceux-ci peuvent être modélisés par des dispositifs techniques, être sujets d'une expérimentation, ou être impliqués dans un processus participatif. Dans ce dernier cas, les simulations sont susceptibles de produire des effets qui dépassent les améliorations techniques de conception., et déboucher sur de nouveaux développements de l'activité individuelle et collective. 
MoTS CLÉS

Simulation, ergonomie participative, théorie de la pratique

\section{RESUMEN}

Las simulaciones ergonómicas se pueden categorizar de acuerdo al lugar que éstas le asignan a los futuros usuarios: éstos pueden ser modelizados mediante dispositivos técnicos, ser sujetos de una experimentación, o estar implicados en un proceso participativo. En este último caso, las simulaciones son susceptibles de producir efectos que sobrepasan las mejoras técnicas de diseño, y desembocar en nuevos desarrollos de la actividad individual y colectiva.

Palabras Clave

Simulación, ergonomía participativa, teoría de la práctica 